\title{
OPEN Toxicity of biogenic zinc oxide nanoparticles to soil organic matter cycling and their interaction with rice-straw derived biochar
}

\author{
Shemawar ${ }^{1}$, Abid Mahmood ${ }^{1}$, Sabir Hussain ${ }^{1}$, Faisal Mahmood ${ }^{1}$, Muhammad Iqbal $^{1}$, \\ Muhammad Shahid ${ }^{2}$, Muhammad Ibrahim ${ }^{1}$, Muhammad Arif Ali $^{3} \&$ Tanvir Shahzad $^{1 凶}$
}

Given the rapidly increasing use of metal oxide nanoparticles in agriculture as well as their inadvertent addition through sewage sludge application to soils, it is imperative to assess their possible toxic effects on soil functions that are vital for healthy crop production. In this regard, we designed a lab study to investigate the potential toxicity of one of the most produced nanoparticles, i.e. zinc oxide nanoparticles ( $\mathrm{nZnO}$ ), in a calcareous soil. Microcosms of $\mathbf{8 0 ~} \mathrm{g}$ of dry-equivalent fresh soils were incubated in mason jars for 64 days, after adding 100 or $1000 \mathrm{mg}$ of biogenically produced $\mathrm{nZnO}$ $\mathrm{kg}^{-1}$ soil. Moreover, we also added rice-straw derived biochar at 1 or $5 \%$ ( $w$ : $w$ basis) hypothesizing that the biochar would alleviate $\mathrm{nZnO}$-induced toxicity given that it has been shown to adsorb and detoxify heavy metals in soils. We found that the $\mathrm{nZnO}$ decreased microbial biomass carbon by 27.0 to $33.5 \%$ in $100 \mathrm{mg} \mathrm{nZnO} \mathrm{kg}^{-1}$ soil and by 39.0 to $43.3 \%$ in $1000 \mathrm{mg} \mathrm{nZnO} \mathrm{kg}^{-1}$ soil treatments across biochar treatments in the short term i.e. 24 days after incubation. However, this decrease disappeared after 64 days of incubation and the microbial biomass in $\mathrm{nZnO}$ amended soils were similar to that in control soils. This shows that the toxicity of $\mathrm{nZnO}$ in the studied soil was ephemeral and transient which was overcome by the soil itself in a couple of months. This is also supported by the fact that the $\mathrm{nZnO}$ induced higher cumulative $\mathrm{C}$ mineralization (i.e. soil respiration) at both rates of addition. The treatment $100 \mathrm{mg} \mathrm{nZnO} \mathrm{kg}^{-1}$ soil induced 166 to $207 \%$, while $1000 \mathrm{mg} \mathrm{nZnO} \mathrm{kg}^{-1}$ soil induced 136 to $171 \%$ higher cumulative $\mathrm{C}$ mineralization across biochar treatments by the end of the experiment. However, contrary to our hypothesis increasing the nZnO addition from 100 to $1000 \mathrm{mg} \mathrm{nZnO} \mathrm{kg}^{-1}$ soil did not cause additional decrease in microbial biomass nor induced higher $\mathrm{C}$ mineralization. Moreover, the biochar did not alleviate even the ephemeral toxicity that was observed after $24 \mathrm{~d}$ of incubation. Based on overall results, we conclude that the studied soil can function without impairment even at $1000 \mathrm{mg} \mathrm{kg}^{-1}$ concentration of $\mathrm{nZnO}$ in it.

During recent decades, engineered nanoparticles (NPs) have gained widespread popularity for their use in agriculture and allied sectors due to their specific characteristics ${ }^{1,2}$. The Food and Agriculture Organization \& the World Bank are also promoting their use in agriculture ${ }^{3}$. This may lead to an exponential increase in use of NPs in agriculture sector. Consequently, their load in agricultural soils is expected to rise. Currently, inadvertent application of NPs in sewage sludge is the main route of NPs' entry to agricultural soils ${ }^{4}$. Increasing use of NPs in agricultural inputs like fertilizers and pesticides would become another source of NPs load in soils in future ${ }^{5,6}$. The input of NPs in agricultural soils can affect soil fauna and flora and thereby the associated agroecosystem services $^{1,7-9}$.

Metal oxide nanoparticles are a major class of NPs that are used in a wide range of products. In a recent synthesis of literature, metal oxide NPs have been reported as one of the most toxic NPs to soil biota ${ }^{8}$. This may cause short to long term loss of soil health and fertility since soil biota are key to these services ${ }^{10-12}$. Numerous studies have been carried out to assess the potential toxic effects of metal oxide NPs on soil invertebrates \&

${ }^{1}$ Department of Environmental Sciences and Engineering, Government College University Faisalabad, Allama Iqbal Road, Faisalabad 38000, Pakistan. 2Department of Bioinformatics and Biotechnology, Government College University Faisalabad, Allama Iqbal Road, Faisalabad 38000, Pakistan. ${ }^{3}$ Department of Soil Science, Bahauddin Zakariya University, Multan, Pakistan. ${ }^{\varpi}$ email: hereistanvir@gmail.com 


\begin{tabular}{|l|l|l|l|}
\hline Parameter & Soil & Rice-straw derived Biochar $(\mathrm{BC})$ & Zinc oxide nanoparticles (nZnO) \\
\hline Sand $(\%)$ & $50.33 \pm 1.76$ & & \\
\hline Silt $(\%)$ & $22.67 \pm 2.33$ & & \\
\hline Clay $(\%)$ & $26.67 \pm 0.33$ & & \\
\hline Textural Class & Sandy clay loam & & \\
\hline pH & $8.25 \pm 0.04$ & $8.97 \pm 0.01$ & \\
\hline Electrical conductivity $\left(\mathrm{d} \mathrm{S} \mathrm{m}^{-1}\right)$ & 0.37 & 1.34 & \\
\hline Organic C $\left(\mathrm{g} \mathrm{kg}^{-1} \mathrm{dry} \mathrm{matter}\right)$ & $6.65 \pm 0.53$ & $281.9 \pm 11.2$ & \\
\hline Total N $\left(\mathrm{g} \mathrm{kg}^{-1}\right.$ soil) & $0.57 \pm 0.05$ & $7.41 \pm 0.97$ & \\
\hline C/N & 11.7 & 38.04 & $90-110$ \\
\hline Size $(\mathrm{nm})$ & & & Granular agglomerated particles \\
\hline Shape & & & -27.41 \\
\hline Zeta potential $(\mathrm{mV})$ & & & \\
\hline
\end{tabular}

Table 1. Pre-incubation physiochemical characteristics of soil, rice-straw derived biochar (BC) and zinc oxide nanoparticles $(\mathrm{nZnO})$.

microorganisms ${ }^{8,10}$. However, studies exploring the effect of metal oxide NPs on the processes that determine soil health \& fertility i.e. soil organic matter decomposition, nutrient cycling, and enzymatic activity are a few.

Among metal oxide NPs, zinc oxide $(\mathrm{ZnO})$ nanoparticles have one of the highest production volumes ${ }^{13,14}$. They are mainly used in different products like cosmetics, medicines, food and solar cells. Owing to their antimicrobial \& antigenic properties, they are widely used for such services like veterinary sciences, food storage, and killing microbes to enhance shelf life of food products ${ }^{8,15}$. Therefore, they may be toxic when released in the environment. Given their widespread use and potential to contaminate soils, it is imperative that their potentially toxic effect on soil processes is determined across different soils.

Biochar, a carbonaceous material made by pyrolyzing organic waste materials, is being promoted as a soil conditioner to enhance soil fertility, water holding capacity, nutrient retention, and soil C storage $\mathrm{e}^{16-18}$. In addition, biochar has also been shown to decrease the toxicity of heavy metals in soil ${ }^{19}$. Since adsorption capacity of biochar is much higher than its precursors, the leachability and bioavailability of heavy metals can be reduced because biochar has large surface area to adsorb heavy metals and organic pollutant ${ }^{20}$. It can, therefore, be imagined that the biochar materials would also be capable of adsorbing metals derived from metal-oxide nanoparticles thereby reducing their toxicity ${ }^{21}$.

Although the potential toxicity of NPs in soil processes has been studied to some extent recently, such kind of studies are rare in calcareous soils. Moreover, the use of biochar to reduce the potential toxicity of NPs has rarely been explored. To fill this gap, we designed a study to explore the effect of $n \mathrm{ZnO}\left(100 \& 1000 \mathrm{mg} n \mathrm{ZnO} \mathrm{kg}^{-1}\right.$ soil) on soil processes related to soil health in a calcareous soil in a lab incubation. We explored following questions: i) how will $n \mathrm{ZnO}$ affect soil processes related to $\mathrm{C}$ and $\mathrm{N}$ cycling in an organic-matter poor, calcareous soil and, ii) if the $n \mathrm{ZnO}$ is toxic to soil processes, will the addition of biochar alleviate that toxicity? We hypothesized that the $n \mathrm{ZnO}$ NPs would negatively affect the soil processes and the increasing $\mathrm{nZnO}$ addition would further toxify the soil processes. We also hypothesized that the rice-straw derived biochar would decrease the toxic effects of $n \mathrm{ZnO}$ on soils processes.

\section{Results}

Characteristics of the nZnO. The Field Emission Scanning Electron Microscope (FESEM) analysis showed that the $\mathrm{nZnO}$ synthesized and used in this study were having granular shape agglomerated particles in the size range of 90-110 $\mathrm{nm}$ (Table 1, Fig. S1). The dynamic light scanning technique revealed that the $\mathrm{nZnO}$ carried a negative zeta potential of $-27.41 \mathrm{mV}$ (Table 1 ). The FT-IR analyses revealed the $\mathrm{OH}$ stretching of intramolecular hydrogen bond, $\mathrm{C}=\mathrm{C}$ bond stretching and $\mathrm{C}-\mathrm{C}$ stretching of Alkanes at peaks obtained at $3740 \mathrm{~cm}^{-1}$, $1644 \mathrm{~cm}^{-1}, 1429 \mathrm{~cm}^{-1}$ and $1013 \mathrm{~cm}^{-122,23}$. Importantly, the stretching vibrations of $\mathrm{ZnO}$ bond were indicated in the peak obtained at $522 \mathrm{~cm}^{-124}$ (Figure S2). The XRD pattern showed characteristic peaks of $\mathrm{nZnO}$ at $2 \theta=32.3^{\circ}$, $35.2^{\circ}, 37^{\circ}, 48.3^{\circ}, 57.4^{\circ}, 63.6^{\circ}, 66.9^{\circ}, 68.9^{\circ}, 70^{\circ}, 73.3^{\circ}, 77.6^{\circ}$ corresponding to (100), (002), (101), (102), (110), (220), (103), (112), (201), (004) and (311) planes (Fig. S3), respectively, and the data are matched well with those reports in literature and the Joint Committee on powder diffraction standards (JCPDS) file No. 04-0783 ${ }^{25}$.

Soil pH. Application of zinc oxide nanoparticles $(\mathrm{nZnO})$ as well as the rice-straw derived biochar $(\mathrm{BC})$ significantly increased the soil $\mathrm{pH}$ (Fig. $1, P<0.05$ ). Addition of $\mathrm{BC}$ at $5 \%$ induced the largest increase in soil $\mathrm{pH}$, i.e. by 0.53 to 0.9 , irrespective of the $\mathrm{nZnO}$ addition. The $\mathrm{nZnO}$ application caused an increase in soil $\mathrm{pH}$ only at $1000 \mathrm{mg} \mathrm{kg}^{-1}$ soil application. The $\mathrm{BC}$ and $\mathrm{nZnO}$ had significant interactive effect on soil $\mathrm{pH}$.

Carbon mineralization. Carbon mineralization significantly changed in response to both treatments i.e. $\mathrm{nZnO} \& \mathrm{BC}$ addition as well as with the time of incubation (Fig. $2, P<0.05$ ). The lower addition of $\mathrm{nZnO}$ (i.e. $100 \mathrm{mg} \mathrm{nZnO} \mathrm{kg}{ }^{-1}$ soil) induced higher $\mathrm{C}$ mineralization $\left(\mathrm{mg} \mathrm{CO}_{2}-\mathrm{C} \mathrm{kg}^{-1}\right.$ soil day $\left.{ }^{-1}\right)$ than the higher $\mathrm{nZnO}$ addition (i.e. $1000 \mathrm{mg} \mathrm{nZnO} \mathrm{kg}{ }^{-1}$ soil). However, both the biochar addition levels induced similar increase in $\mathrm{C}$ mineralization overall. There were two distinct phases of $\mathrm{C}$ mineralization i.e. first phase over 0-24 days 


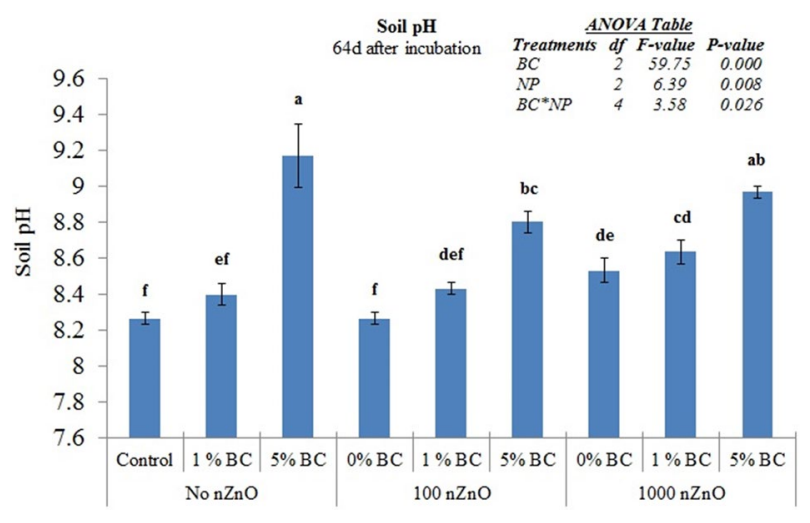

Figure 1. Soil $\mathrm{pH}$ as affected by zinc oxide $(\mathrm{nZnO})$ and rice-straw derived biochar after $64 \mathrm{~d}$ of incubation. Different small letters on top of bars represent post-hoc HSD difference at 95\% confidence intervals. Error bars represent standard errors of means $(n=3)$.

of incubation (Fig. 2A, C, E) \& the second phase spread over 25-64 days of incubation (Fig. 2B, D, F). Briefly, the treatments-induced increase was very high in the initial phase. For some measures, both nZnO \& BC had synergistic effect to increase the $\mathrm{C}$ mineralization e.g. adding biochar with $100 \mathrm{mg} \mathrm{nZnO} \mathrm{kg}{ }^{-1}$ soil significantly increased C mineralization than their individual effects. The increase in C mineralization tapered off from 20th day of incubation onwards in a way that the treatments did not differ with the control soil in terms of $\mathrm{C}$ mineralization from 45th day of incubation.

As a corollary to $\mathrm{C}$ mineralization rates, the cumulative $\mathrm{C}$ mineralization was significantly higher for both

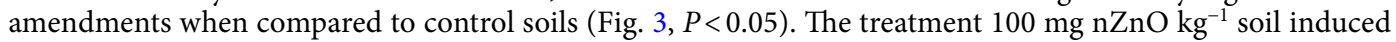
166 to $207 \%$ while $1000 \mathrm{mg} \mathrm{nZnO} \mathrm{kg}{ }^{-1}$ soil induced 136 to $171 \%$ higher cumulative $\mathrm{C}$ mineralization across biochar treatments by the end of the experiment. The lower $\mathrm{nZnO}$ addition induced higher cumulative $\mathrm{CO}_{2}-\mathrm{C}$ release across all the treatments. However, both the $\mathrm{BC}$ treatments i.e. 1 \& $5 \%$ addition did not differ in terms of final cumulative $\mathrm{CO}_{2}-\mathrm{C}$ release. The interactive effect of $\mathrm{nZnO} \& \mathrm{BC}$ was the most prominent when $1 \% \mathrm{BC}$ was added to $100 \mathrm{NP}$ treatment (100NP $1 \%$ BC) such that this treatment showed highest cumulative $\mathrm{C}$ mineralization from 10th day of incubation till the end.

Microbial biomass (MBC), dissolved organic carbon (DOC) \& metabolic quotient. Both microbial biomass carbon and dissolved organic carbon were measured twice: first, they were determined after 24 days of incubation whereas second measurement was done at the end of the incubation.

The MBC was significantly reduced by $\mathrm{nZnO}$ at both application rates for the first measure (Fig. $4 \mathrm{~A}, \mathrm{P}<0.05$ ). This decrease was by 27.0 to $33.5 \%$ in $100 \mathrm{mg} \mathrm{nZnO} \mathrm{kg}^{-1}$ soil and by 39.0 to $43.3 \%$ in $1000 \mathrm{mg} \mathrm{nZnO} \mathrm{kg}^{-1}$ soil treatments across biochar treatments. Both levels of $\mathrm{nZnO}$ addition induced similar decrease. Biochar did not induce any change in MBC at this stage, nor its interaction with $\mathrm{nZnO}$. At the end of the incubation, no effect of $\mathrm{nZnO}$ application on MBC was observed (Fig. 4B). However, BC application at both rates (1 \& 5\%) significantly reduced the $\mathrm{MBC}(P<0.05)$. The $\mathrm{BC}$ and $\mathrm{nZnO}$ application had a positive interactive effect on $\mathrm{MBC}$ such that the $\mathrm{MBC}$ increased in $100 \mathrm{nZnO} 5 \% \mathrm{BC}, 1000 \mathrm{nZnO} 1 \% \mathrm{BC}$ and $1000 \mathrm{nZnO} 5 \% \mathrm{BC}$ treatments when compared to BC $(1 \& 5 \%)$ only treatments.

At 24th day of incubation, the dissolved organic carbon (DOC) was significantly increased by application of zinc oxide nanoparticles as well as biochar (Fig. $4 \mathrm{C}, P<0.05$ ). The rates of application of both the amendments did not differ in terms of DOC content. Similarly, there was no interactive effect of $\mathrm{nZnO}$ and BC. At the end of the incubation, $\mathrm{nZnO}$ had no effect on DOC whereas BC only treatments (1 \& 5\% BC) showed significantly higher DOC content than control (Fig. 4D, $P<0.05$ ). The NP and biochar treatments had interactive effect on DOC such that all of their combinations showed DOC content similar to those in control. However, the treatment 100NP 1\% BC was an exception where the DOC content was significantly higher than control. The harvest time did not have any effect on DOC.

Metabolic quotient $\left(\mathrm{qCO}_{2}\right), \mathrm{CO}_{2}-\mathrm{C}$ released per unit of microbial biomass, was significantly increased by both $\mathrm{nZnO} \& \mathrm{BC}$, as well as, their interaction after 24 days of incubation (Fig. 4E). The addition of $1 \% \mathrm{BC}$ with low $\mathrm{nZnO}$ addition caused the highest $\mathrm{qCO}_{2}$. After 64 days of incubation too, the $\mathrm{qCO}_{2}$ was significantly increased by both amendments (Fig. 4F). However, there was not interactive effect after 64 days of incubation.

Mineral nitrogen \& available phosphorus content. Nanoparticle application significantly changed the mineral $\mathrm{NO}_{3}^{-}-\mathrm{N}$ content in soils whereas the biochar application did not affect it (Table 2). Moreover, there was a significant nanoparticle $\times$ biochar effect on nitrate content. Unexpectedly, no increase was observed in $\mathrm{NO}_{3}{ }^{-}-\mathrm{N}$ content with biochar addition. The addition of $\mathrm{nZnO}$ in low amount (i.e. $100 \mathrm{mg} \mathrm{nZnO} \mathrm{kg}{ }^{-1}$ soil) significantly increased the $\mathrm{NO}_{3}{ }^{-}-\mathrm{N}$ content, whereas addition of biochar along with it did not cause any further change. However, increasing the $\mathrm{nZnO}$ addition amount to $1000 \mathrm{mg} \mathrm{nZnO} \mathrm{kg}{ }^{-1}$ soil did not cause any change in the $\mathrm{NO}_{3}{ }^{-}-\mathrm{N}$ content with respect to control. Addition of biochar at $5 \%$ rate along with $1000 \mathrm{mg} \mathrm{nZnO} \mathrm{kg}{ }^{-1}$ soil increased the $\mathrm{NO}_{3}{ }^{-} \mathrm{N}$ content to those found in $100 \mathrm{mg} \mathrm{nZnO} \mathrm{kg}^{-1}$ soil treatments, though addition of biochar at 


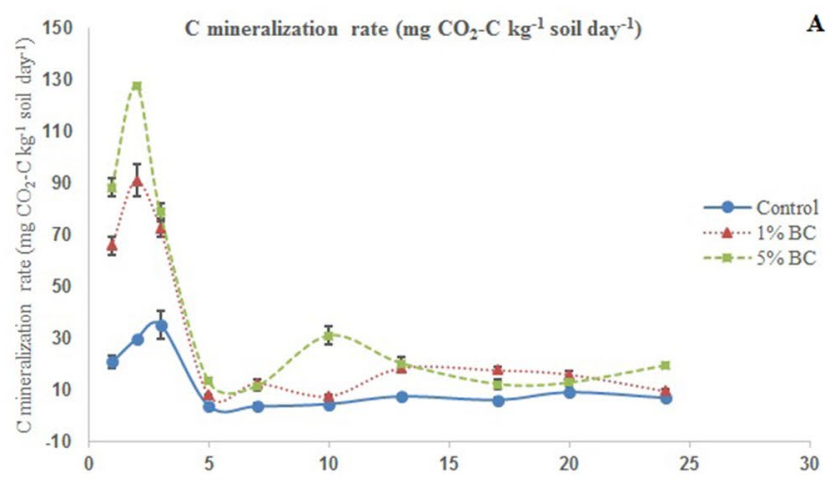

A $\quad 150$

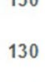

130

110

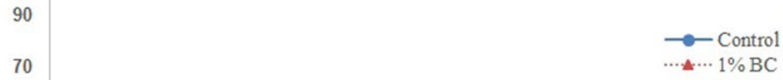

70

30
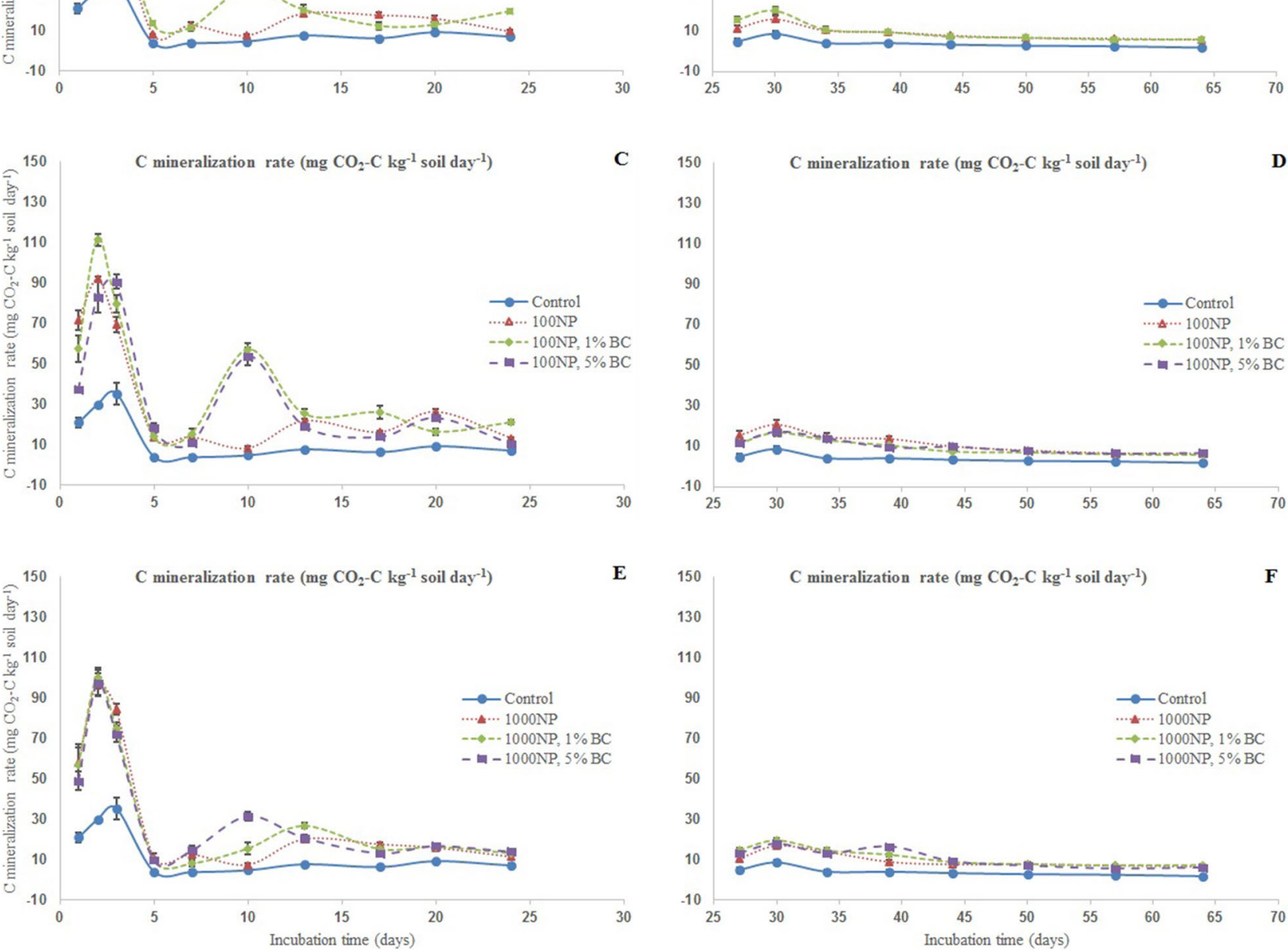

Figure 2. Carbon mineralization rate $\left(\mathrm{mg} \mathrm{CO}_{2}-\mathrm{C} \mathrm{kg}^{-1}\right.$ soil day $\left.{ }^{-1}\right)$ as affected by zinc oxide (nZnO) and ricestraw derived biochar after $24 \mathrm{~d}$ (panels A, C, E) \& 64d (B, D, F) of incubation. C mineralization in different BC, $\mathrm{nZnO}$ and $\mathrm{BC}+\mathrm{nZnO}$ treatments for a given date have been plotted in different panels (e.g. panels $\mathbf{A}, \mathbf{C}, \mathbf{E}$ ) for the purpose of simplification.

$1 \%$ did not cause any increase. No treatment effect was observed on $\mathrm{NH}_{4}{ }^{+}-\mathrm{N}$ content. Mineral $\mathrm{N}$, calculated by adding $\mathrm{NH}_{4}{ }^{+}-\mathrm{N}$ and $\mathrm{NO}_{3}{ }^{-} \mathrm{N}$, was changed by $\mathrm{nZnO}$ in the way similar to $\mathrm{NO}_{3}{ }^{-} \mathrm{N}$ content.

Both the treatments, $\mathrm{ZnO}$ nanoparticles as well as biochar, induced significant increase in available P (Fig. 5). The highest increase was observed in biochar only treatments. Although, NP treatments also induced significant increase in P availability, their combination with BC did not show any additional increase, rather it decreased the available $\mathrm{P}$ when compared to biochar only treatments.

Bacterial colony forming units. None of the two treatments affected bacterial colony forming units (CFU) (Fig. 6, $P>0.05)$.

\section{Discussion}

$\mathrm{ZnO}$ nanoparticles $(\mathrm{nZnO})$ significantly reduced the microbial biomass carbon (MBC) in the short term, i.e. when measured on 24th day of incubation (Fig. 4A). This result partially proves our first hypothesis i.e. the $\mathrm{nZnO}$ induced toxicity in our soil. Reduced microbial biomass was observed in a grassland soil 15 \& 60 days after application of $\mathrm{nZnO}^{26}$. Moreover, they found an exponential decrease in $\mathrm{MBC}$ with increasing concentration of $\mathrm{nZnO}$ (i.e. $50,100 \& 500 \mathrm{mg} \mathrm{kg}^{-1}$ soil). However, in our study, increasing the $\mathrm{nZnO}$ concentration from 


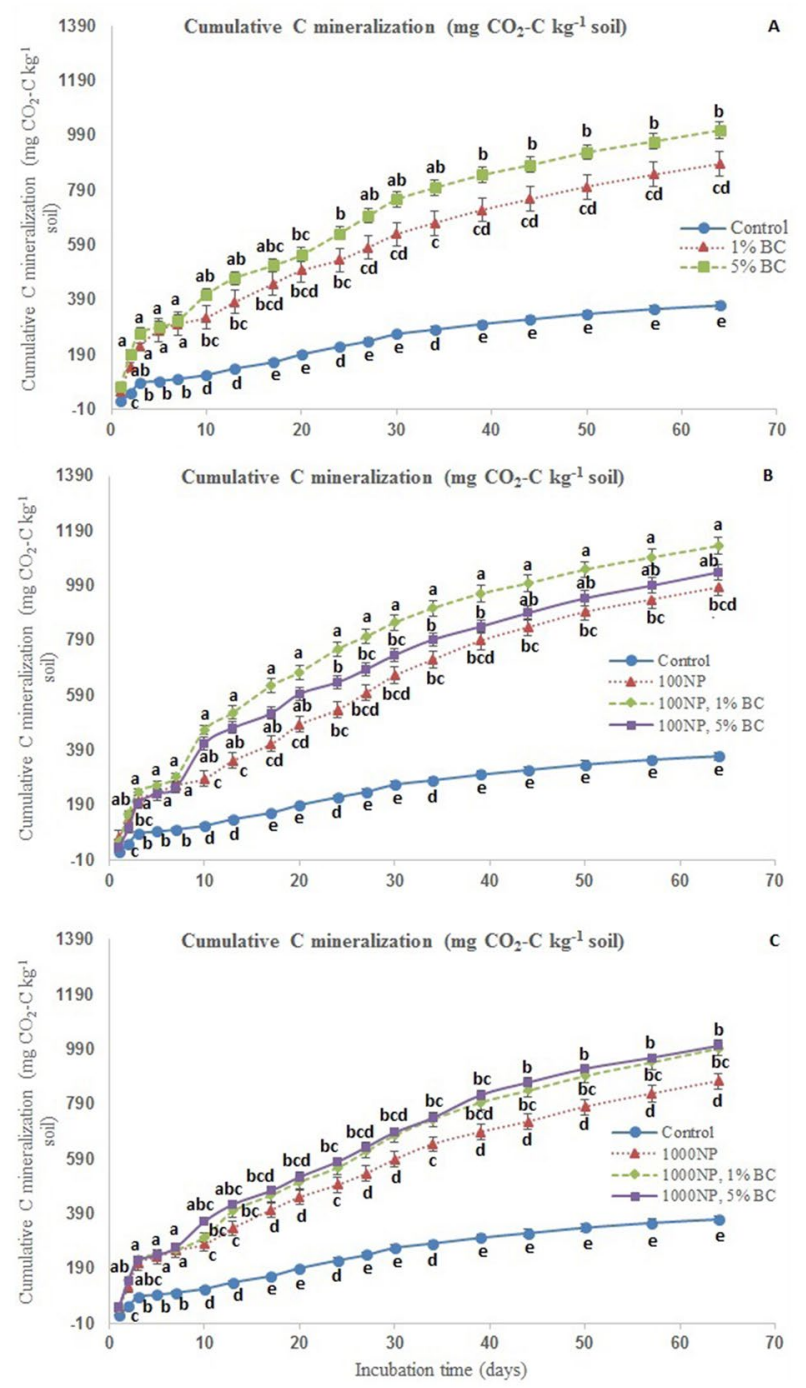

Figure 3. Cumulative carbon mineralization ( $\mathrm{mg} \mathrm{CO}_{2}-\mathrm{C} \mathrm{kg}^{-1}$ soil) as affected by zinc oxide ( $\mathrm{nZnO}$ ) and rice-straw derived biochar over 64 days of incubation. Cumulative $\mathrm{C}$ mineralization in different $\mathrm{BC}, \mathrm{nZnO}$ and $\mathrm{BC}+\mathrm{nZnO}$ treatments for a given date have been plotted in different panels (e.g. panels $\mathbf{A}, \mathbf{C}, \mathbf{E}$ ) for the purpose of simplification. Different small letters on treatment points across three panels represent post-hoc HSD difference at $95 \%$ confidence interval.

100 to $1000 \mathrm{mg} \mathrm{kg}^{-1}$ soil did not cause further decrease in MBC. This is intriguing though not unexpected given the overall ephemeral toxicity of the $\mathrm{nZnO}$ observed in this study. In a previous study, toxicity of nZnO doses vis-à-vis microbial biomass was dependent on sensitivity of the method used to estimate the microbial biomass. The DNA extraction showed an exponential decrease with increasing dose of $\mathrm{nZnO}$ from 50 to $500 \mathrm{mg} \mathrm{kg}^{-1}$ soil, whereas substrate-induced respiration, i.e. a method more similar to fumigation-extraction used in this study than the DNA extraction, found no change within $\mathrm{nZnO}$ doses after 15 days of exposure ${ }^{26}$. Moreover, the MBC in $\mathrm{nZnO}$ amended soils recovered to that found in control after 64 days of incubation in our study. These results indicate that the toxicity of the $\mathrm{nZnO}$ used in this study was transient and ephemeral. The unchanged culturable bacteria also support the transient nature of the toxicity induced by $\mathrm{nZnO}$ in our soil.

Our second hypothesis was that biochar would mitigate the toxic effects induced by the nZnO. However, this was not the case as the MBC after 24 days of incubation remained lower in $\mathrm{nZnO}$ amended soils than the control soils even after addition of $1 \%$ or $5 \%$ BC (Fig. $4 \mathrm{~A}$ ). The toxicity of $\mathrm{nZnO}$, or any metal oxide nanoparticle for that matter, is related to the extent of its dissolution and subsequent availability of its constituent metal ions to microbes ${ }^{27,28}$. Although we did not measure dissolution of $\mathrm{nZnO}$ used in our study nor did we measure the possible microbial uptake of $\mathrm{Zn}^{2+}$, this nanomaterial is known for its easy dissolution in soils ${ }^{29,30}$. Moreover, the FESEM and XRD analyses have confirmed the active nano nature of the $\mathrm{nZnO}$ particles. Therefore, it can be assumed that the transient toxicity induced by $\mathrm{nZnO}$ in our study was due to $\mathrm{Zn}^{2+}$ ions released and absorbed by microbes after dissolution of $\mathrm{nZnO}^{26,30,31}$. The biochar, being an organic material and known as sorbent for heavy metals, was expected to complex ionic zinc thereby reducing the toxicity. On the contrary, biochar itself decreased MBC by the end of the incubation (Fig. 4B). Addition of biochar to soils usually increases MBC $^{32}$. 

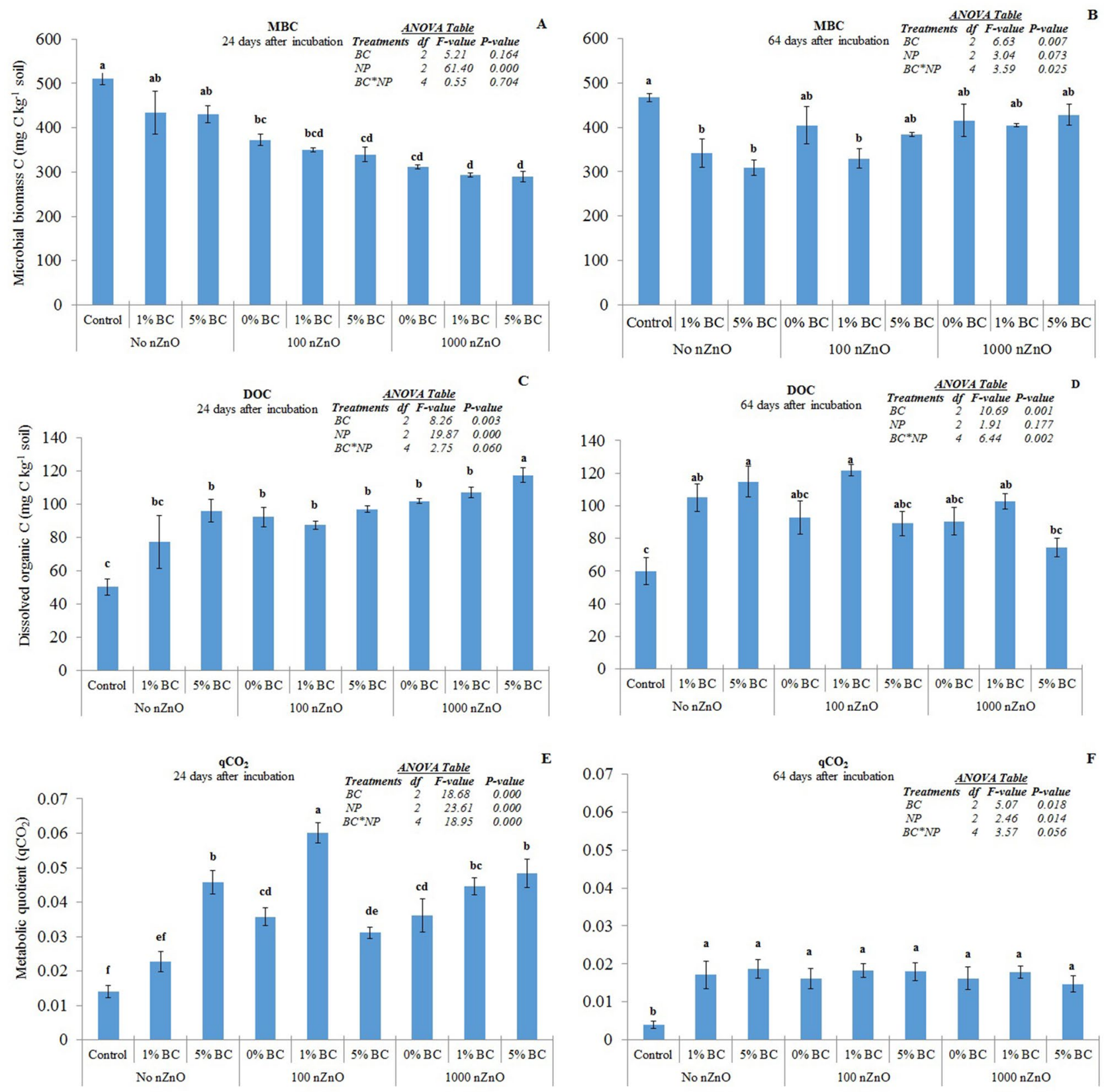

Figure 4. Microbial biomass $\mathrm{C}$, dissolved organic $\mathrm{C}$ and metabolic quotient in response to $\mathrm{nZnO}$ and $\mathrm{BC}$ treatments after 24 (panels A, C, E respectively) and 64 days (panels B, C, F respectively). Different small letters on top of bars represent post-hoc HSD difference at $95 \%$ confidence interval. Error bars represent standard errors of means $(n=3)$.

However, it may not induce any change or reduce the $\mathrm{MBC}$ as well ${ }^{17,33,34}$. For instance, rice-straw derived biochar reduced the $\mathrm{MBC}$ in another study ${ }^{34}$; a result which corresponds to our study. Volatile organic compounds on the surface of biochars may cause toxicity to microbial biomass ${ }^{33}$.

Both the treatments i.e. $\mathrm{nZnO} \& \mathrm{BC}$ increased the $\mathrm{CO}_{2}-\mathrm{C}$ release from soils (Figs. 2, 3) as well as metabolic quotients, which, over time, tapered off to that coming out of control soils (Figs. 2, 3). In a previous study, nZnO were found to induce no change in soil respiration at $0.1-100 \mathrm{mg} \mathrm{kg}^{-1}$ soil addition whereas a reduction at $1000 \mathrm{mg} \mathrm{kg}^{-1}$ soil addition was observed ${ }^{35}$. However, activity of dehydrogenase, cellobiohydrolase, xylosidase \& glucosidase enzymes, which are linked with $\mathrm{CO}_{2}-\mathrm{C}$ release, were found to increase after exposure to $\mathrm{nnO}^{28,29,36}$. The increase in $\mathrm{CO}_{2}$-C release in response to heavy metal ions (i.e. $\mathrm{Zn}^{2+}$ in our study) can be the result of two processes: turnover of microbial biomass \& stress induced increases in metabolic quotients ${ }^{31,37}$. Until 24 th day of incubation in our study, both the processes seem to contribute to increase in respiration in response to nZnO addition given the significant decrease in MBC and very high metabolic quotients. In the second phase, the increase in respiration was nominal thereby resulting in less prominent metabolic quotients. Even if there was 


\begin{tabular}{|c|c|c|c|}
\hline \multicolumn{4}{|l|}{64 Days of incubation } \\
\hline Treatments & $\mathrm{NO}_{3}{ }^{-} \mathrm{N}_{\mu \mathrm{g} \mathrm{g}^{-1}}$ soil & $\mathrm{NH}_{4}{ }^{+}-\mathrm{N}_{\mu} \mathrm{g} \mathrm{g}^{-1}$ soil & Mineral N \\
\hline Control & $17.5(3.6) \mathrm{cd}^{*}$ & $0.01(0.0) \mathrm{a}$ & 17.5 (3.6)de \\
\hline $1 \% \mathrm{BC}$ & $18.3(4.0) \mathrm{bc}$ & $0.05(0.01) \mathrm{a}$ & $18.4(4.0) \mathrm{cde}$ \\
\hline $5 \% \mathrm{BC}$ & $19.3(3.0) \mathrm{abcd}$ & $0.06(0.03) \mathrm{a}$ & 19.4 (3.0)bcde \\
\hline $100 \mathrm{nZnO}$ & $24.8(1.0) \mathrm{ab}$ & $0.06(0.02) \mathrm{a}$ & $24.9(1.0) \mathrm{ab}$ \\
\hline $100 \mathrm{nZnO}, 1 \% \mathrm{BC}$ & $25.8(0.6) \mathrm{a}$ & $0.04(0.01) \mathrm{a}$ & $25.8(0.6) \mathrm{a}$ \\
\hline $100 \mathrm{nZnO}, 5 \% \mathrm{BC}$ & $24.2(0.4) \mathrm{ab}$ & $0.05(0.01) \mathrm{a}$ & $24.3(0.4) \mathrm{abc}$ \\
\hline $1000 \mathrm{nZnO}$ & $17.2(0.5) \mathrm{d}$ & $0.03(0.01) \mathrm{a}$ & $17.2(0.5) \mathrm{e}$ \\
\hline $1000 \mathrm{nZnO}, 1 \% \mathrm{BC}$ & $14.6(1.2) \mathrm{d}$ & $0.04(0.0) \mathrm{a}$ & $14.6(1.2) \mathrm{e}$ \\
\hline $1000 \mathrm{nZnO}, 5 \% \mathrm{BC}$ & $23.9(1.7) \mathrm{abc}$ & $0.03(0.01) \mathrm{a}$ & $23.9(1.7) \mathrm{abcd}$ \\
\hline
\end{tabular}

Table 2. Effect of $\mathrm{nZnO} \& \mathrm{BC}$ on $\mathrm{NO}_{3}{ }^{-} \mathrm{N}, \mathrm{NH}_{4}{ }^{+}-\mathrm{N}$ and mineral N. Different letters within a column indicate significant difference between means at $95 \%$ confidence interval. The brackets contain standard errors of means $(n=3)$.

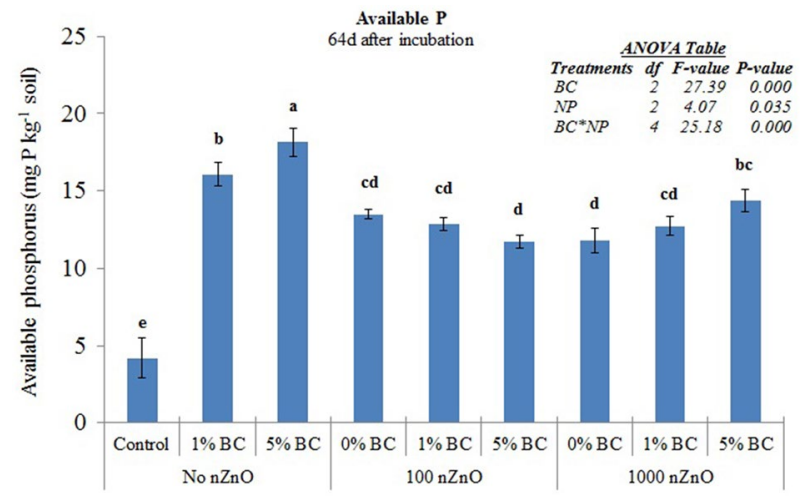

Figure 5. Available phosphorus in soils in response to $\mathrm{nZnO}$ and $\mathrm{BC}$ treatments $64 \mathrm{~d}$ after incubation. Different small letters on top of bars represent post-hoc HSD difference at $95 \%$ confidence interval. Error bars represent standard errors of means $(n=3)$.

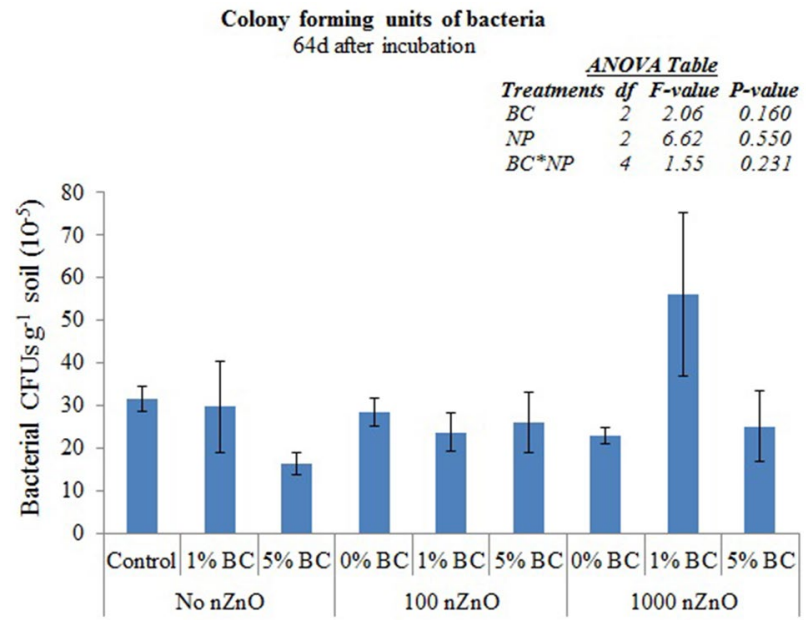

Figure 6. Colony forming units (CFUs) of bacteria found in soils in response to $\mathrm{nZnO}$ and $\mathrm{BC}$ treatments 64d after incubation. Error bars represent standard errors of means $(n=3)$. 
no decrease in MBC in the second phase, the microbes are stressed in presence of heavy metal ions, inefficient to use substrates (i.e. biochar in our case) and have to expend more energy for maintenance than assimilation ${ }^{37}$.

Intuitively, increase in dissolved organic carbon (DOC) should increase the microbial biomass ${ }^{38}$. Both $\mathrm{nZnO}$ as well as BC induced increase in DOC on both occasions; more prominent during the first phase (Fig. 4C, D). However, this increase in DOC did not translate into increase in MBC. The literature shows that this may not be an anomaly ${ }^{39}$. The increase in DOC in our study may be linked to increase in soil $\mathrm{pH}$ by both treatments. In a survey of 33 alkaline soils (i.e. $\mathrm{pH}>8$ ) in Australia, DOC was found in a positive relationship with $\mathrm{pH}$ suggesting that the increase in $\mathrm{pH}$ enhances solubility of DOC and stimulates desorption of DOC from mineral sites ${ }^{40}$.

The response of mineral nitrogen availability to $\mathrm{nZnO}$ was enigmatic (Table 2). The $100 \mathrm{mg} \mathrm{nZnO} \mathrm{kg}{ }^{-1}$ soil treatment induced a significant increase while $1000 \mathrm{mg} \mathrm{nZnO} \mathrm{kg}{ }^{-1}$ soil did not induce any change in it. This result corresponds to some previous studies. For instance, $10 \& 100 \mathrm{mg} \mathrm{nZnO} \mathrm{kg}{ }^{-1}$ soil significantly increased the $\beta$-1,4-N-acetylglucosaminidase activity implying an increase in mineral $\mathrm{N}^{29}$. However, the $\mathrm{nZnO}$ in 10 , $100 \& 1000 \mathrm{mg} \mathrm{nZnO} \mathrm{kg}{ }^{-1}$ soil concentrations have been reported to inhibit urease activity thereby implying lower availability of mineral $\mathrm{N}^{28}$, whereas no effect of the same have also been reported at same addition rates ${ }^{35}$. However, the decrease in mineral $\mathrm{N}$ at $1000 \mathrm{mg} \mathrm{nZnO} \mathrm{kg}^{-1}$ soil cannot be explained based on our data. The no decrease in soil mineral $\mathrm{N}$ in response to biochar only additions is expected given that the microbes may immobilize mineral $\mathrm{N}$ present in solution in order to decompose the organic matter i.e. biochar ${ }^{17,41}$. Although these may explain our results to some extent, the effect of metal oxide nanoparticles on nitrogen dynamics in soils warrant detailed investigations. The available phosphorus (P) increased in all the treatments (Fig. 5). It is common for biochar to increase the $\mathrm{P}$ availability given that it releases this nutrient on decomposing ${ }^{32,41}$. The decrease in available phosphorus after $\mathrm{nZnO}$ addition along with biochar compared to biochar only treatments indicate that there is some kind of restraint put by $\mathrm{nZnO}$ on microbes or solubilization process responsible for release of phosphorus in the solution. The composites of metal oxide nanoparticles have been shown to adsorb phosphorus from the aqueous medium, although the same has not been reported for soil so far ${ }^{42}$. Irrespective of the mechanism, this result shows that the $\mathrm{nZnO}$ could negate the benefit of nutrient accrual from biochar. As far the available $\mathrm{P}$ increase in response to $\mathrm{nZnO}$ application, no study have so far reported the effect of $\mathrm{nZnO}$ on $\mathrm{P}$ availability. However, activities of $\mathrm{P}$ cycling enzymes in response to $\mathrm{nZnO}$ have been reported. For instance, alkaline phosphatase activity has been found to significantly increase by $\mathrm{nZnO}$ application at the concentrations of 10 to $1000 \mathrm{mg} \mathrm{nZnO} \mathrm{kg}{ }^{-1}$ soil supporting our result ${ }^{28,29,36}$. These authors found that the $\mathrm{nZnO}$ indeed inhibited the alkaline phosphatase activity within few hours of application while stimulated it after 30 days of exposure. They suspected that the $\mathrm{nZnO}$ might have been complexed by soil organic matter over time. These results combined with our study suggest that the interactions of nanoparticles with nutrient cycling and their mechanistic bases are complicated and need further investigations.

In conclusion, we can say that the biogenically produced zinc oxide nanoparticles showed ephemeral and transient toxicity to microbial biomass in our soil and that this toxicity vanishes after 64 days of incubation. This apparent contradiction of our results with respect to literature is most likely due to the biogenic nature of the $\mathrm{nZnO}$ particles used in our study. To our knowledge, this is the first study reporting the toxicity assessment of biogenic metal oxide nanoparticles to soil processes. The agglomerated nature of the biogenic $\mathrm{nZnO}$ used in our study could explain their ephemeral toxicity given that the agglomeration renders nanoparticles less toxic by reducing the effective volume ratio and surface area ${ }^{43,44}$. Moreover, contrary to our second hypothesis, the biochar did not alleviate this minor toxicity induced by the $\mathrm{nZnO}$. Overall, we can say that the studied soil can function without impairment even at $1000 \mathrm{mg} \mathrm{kg}^{-1}$ concentration of biogenic $\mathrm{nZnO}$ in it.

\section{Methods}

Soil, ZnO nanoparticles and biochar. A surface soil $(0-20 \mathrm{~cm})$ was sampled from agronomy farm of University of Agriculture, Faisalabad. The sampled field has been under wheat-maize crop rotation for more than a decade. Five cores were taken from random locations of the selected plot. All the root debris and gravels were removed with hand before sieving the soil through a $2 \mathrm{~mm}$ sieve. The soil cores were mixed together to make a composite sample for further use in the experiment. The soil has been characterized as a calcareous one with very low organic matter content (Table 1$)$.

The biogenic zinc oxide nanoparticles $(\mathrm{nZnO})$ used in this study were primarily synthesized for degradation of dyes present in the wastewater released by textile industry. They showed excellent potential of degrading a multitude of azo dyes ${ }^{25}$. The next logical step was to ascertain its toxicity in soil environment. For synthesis of zinc oxide nanoparticles ( $\mathrm{nZnO}$ ), an NOs synthesizing bacterial strain Psedochrobactrum sp. C5 was inoculated in $50 \mathrm{~mL}$ nutrient broth medium and incubated for growth under shaking $(150 \mathrm{rpm})$ for $24 \mathrm{~h}$ at $28^{\circ} \mathrm{C}$ under dark. This $50 \mathrm{~mL}$ culture was then added with $0.003 \mathrm{M}$ zinc acetate salt and incubated under shaking at $150 \mathrm{rpm}$ at $28^{\circ} \mathrm{C}$. After $72 \mathrm{~h}$, the culture was collected and cell free supernatant was oven dried at $85^{\circ} \mathrm{C}$. This powder was calcined for $7 \mathrm{~h}$ in muffle furnace at $700{ }^{\circ} \mathrm{C}$ and then ground into a fine powder. The functional groups present on the $\mathrm{nZnO}$ were determined by analyzing the particles in a Fourier Transform Infrared spectroscopy (FTIR- Bruker TENSOR-27) in the spectral range of $2000-500 \mathrm{~cm}^{-1}$. Particle morphology and micro structure of the $\mathrm{nZnO}$ were determined by field emission scanning electron microscopy (FESEM, LEO 1530, Germany). $\mathrm{X}$-ray diffraction was employed to estimate the crystallinity of the $\mathrm{nZnO}$. The zeta potential of the $\mathrm{nZnO}$ was determined by dynamic light scanning technique (Zeta PALS, Brookhaven Instrument Corp., Holtsville, NY, USA) after the $\mathrm{nZnO}$ particles were dispersed in distilled water and sonicated for five minutes to break the bonds between the particles.

Dried rice straw was used to make biochar using the process described previously by our lab ${ }^{17}$. Briefly, well dried small pieces of rice straw were placed in a Pyrex flask of $2 \mathrm{~L}$ inside a muffle furnace. The pyrolysis was performed $550{ }^{\circ} \mathrm{C}$ with the heating rate of approximately $10^{\circ} \mathrm{C} \mathrm{min}^{-1}$. 
Soil incubation. An incubation experiment was carried out where soils amended with zinc oxide nanoparticles $(\mathrm{nZnO})$ in the presence or absence of rice-straw derived biochar (BC) were incubated for 64 days. For each treatment, eighty grams dry weight equivalent of fresh soil were weighed in glass beakers. After adjusting the moisture content of the soils at $60 \%$ of the water holding capacity, soils were sealed in 1L Mason jars and pre-incubated at $20^{\circ} \mathrm{C}$ for two weeks. The pre-incubation was meant for the soil microbial activity to stabilize $\mathrm{s}^{45}$. Incubations were in triplicates with three levels of $\mathrm{nZnO}(0,100,1000 \mathrm{mg} / \mathrm{kg}$ soil $)$ and $\mathrm{BC}(0,1$, and $5 \%$ on weight basis). These levels of NP addition were chosen based on the range i.e. $100-6400 \mathrm{mg} \mathrm{kg}^{-1}$ soil for assessing toxicity to soil processes, as previously described ${ }^{11,46}$. At the end of the pre-incubation, soils were amended with $\mathrm{nZnO}$ and/or BC. The nanoparticles and biochar were mixed with soil in powdered form. Un-amended soils, which were used as controls, were also mixed using spatula to apply uniform soil disturbance across all the treatments. All the treated and control soils were incubated along with one vial of $10 \mathrm{ml} 1 \mathrm{M} \mathrm{NaOH}$ to capture the $\mathrm{CO}_{2}$ emissions. Another vial containing $10 \mathrm{ml}$ distilled water was placed inside the incubation jars to avoid drought in the mason jars. Sealed Jars having $\mathrm{NaOH}$ and $10 \mathrm{ml}$ distilled water, with no soil containing microcosms, were used as blanks for the correction of ambient $\mathrm{CO}_{2}$ concentration. The collected samples were titrated for excess of $\mathrm{NaOH}$ against $1 \mathrm{M} \mathrm{HCl}$ solution to measure $\mathrm{CO}_{2}$. Thereafter, the mason jars were sealed tightly with screw lids to avoid $\mathrm{CO}_{2}$ leakage. In order to measure $\mathrm{C}$ mineralization $\left(\mathrm{CO}_{2}\right.$ emissions from soils), the $\mathrm{NaOH}$ containing vials were routinely taken out for $\mathrm{CO}_{2}$ measurement and were replaced with fresh $\mathrm{NaOH}$-containing vials in mason jars. The harvested $\mathrm{NaOH}$ was titrated with $1 \mathrm{M} \mathrm{HCl}$ after precipitating the carbonates by adding $2 \mathrm{ml}$ of $\mathrm{BaCl}_{2}$. Two drops of phenolphthalein were added as indicator to determine the excess non-reacted $\mathrm{NaOH}$, on the basis of which $\mathrm{CO}_{2}-\mathrm{C}$ trapped in $\mathrm{NaOH}$ was determined ${ }^{47,48}$. At each $\mathrm{NaOH}$ replacement, the soil water content was adjusted to $60 \%$ of water holding capacity by adding distilled water whenever it was needed based on the gravimetric measurement.

Soil analyses. Soil was harvested twice for different analyses. First aliquots of about $25 \mathrm{~g}$ fresh soil were taken out from microcosms after $24 \mathrm{~d}$ of incubation. The second harvest was done at the end of the experiment i.e. after $64 \mathrm{~d}$ of incubation. Microbial biomass $\mathrm{C}$ and dissolved organic $\mathrm{C}$ were measured on both harvests whereas all the other soil analyses were done only on final harvest.

Fumigation extraction method was used to determine the microbial biomass $\mathrm{C}^{49}$. Ten $\mathrm{g}$ of moist soil taken from each microcosm was split into two parts. One part of $5 \mathrm{~g}$ moist soil was fumigated with ethanol free $\mathrm{CHCl}_{3}$ in a vacuum desiccator for $48 \mathrm{~h}$ at $25^{\circ} \mathrm{C}$. After removing the fumigants, $25 \mathrm{~mL}$ of $0.5 \mathrm{M} \mathrm{K}_{2} \mathrm{SO}_{4}$ was used to extract each sample after shaking for $30 \mathrm{~min}$ on a reciprocal shaker. Whatman filter paper were used to filter the extracts. Similar method was used to extract non-fumigated soil ${ }^{49}$. The dissolved organic carbon in the extracts was determined by using the modified Walkley-Black method ${ }^{50,51}$. The difference of soluble $\mathrm{C}$ between fumigated and non-fumigated samples after accounting for an extraction factor of 0.45 was recorded as $\mathrm{MBC}^{52}$. The $\mathrm{C}$ concentration from the non-fumigated soil samples was considered as dissolved organic carbon (DOC) ${ }^{53}$. We also calculated the metabolic quotient $\left(\mathrm{qCO}_{2}\right)$ from the method adapted from Dilly and Munch (Dilly and Munch 1998) who defined this as a ratio between respiration rate and microbial biomass carbon. The $\mathrm{C}$ mineralization measured after $24 \mathrm{~d} \& 64 \mathrm{~d}$ of incubation were used to calculate the metabolic quotient.

Soil $\mathrm{pH}$ was measured using a Jenway $\mathrm{pH}$ meter by mixing soil with distilled water (1:5, w: $\mathrm{v}$ ratio) and shaking the suspension for $30 \mathrm{~min}$ on a shaker. The nitrate content in soil solution $\left(\mathrm{NO}_{3}-\mathrm{N}\right)$ were determined using the salicylic acid nitration method ${ }^{54}$. Briefly, $10 \mathrm{~g}$ of fresh soil was extracted with $20 \mathrm{ml}$ of $0.5 \mathrm{M} \mathrm{K}_{2} \mathrm{SO}_{4}$ after shaking for $30 \mathrm{~min}$ at $60 \mathrm{rpm}$. The extracts were filtered through $\mathrm{N}$-free filter paper. A $0.5 \mathrm{ml}$ of the filtrate and standard (prepared using $\mathrm{KNO}_{3}$ ) was pipetted in clearly labelled test tubes. One $\mathrm{ml}$ of $5 \%$ salicylic acid solution prepared in sulfuric acid was added to each test tube followed by mixing on a vortex mixer and a rest of $30 \mathrm{~min}$. Afterwards, $10 \mathrm{ml}$ of $4 \mathrm{M} \mathrm{NaOH}$ was added to each test tube followed by a rest of $1 \mathrm{hr}$ for full color development. The absorbance was then read on a UV-visible spectrophotometer at $410 \mathrm{~nm}$.

The ammonium content in soil solution $\left(\mathrm{NH}_{4}{ }^{+}-\mathrm{N}\right)$ were determined by using Indophenol blue method ${ }^{55}$. Briefly, $5 \mathrm{~g}$ of fresh soil were extracted with $20 \mathrm{ml}$ of $2 \mathrm{M} \mathrm{KCl}$ after $1 \mathrm{hr}$ of shaking. Calibration standards were prepared with an ammonium salt. For photometric analysis, $5 \mathrm{ml}$ of filtrate (or standard) were pipetted into a test tube. Two and half $\mathrm{ml}$ of a reagent that was prepared by mixing equal volumes of $0.3 \mathrm{M} \mathrm{NaOH}$ and $1.06 \mathrm{M}$ sodium salicylate was added to the test tubes. Moreover, $1 \mathrm{ml}$ of $39.1 \mathrm{mM}$ sodium dichloroisocyanurate solution was also added. The mixture was shaken well and allowed to stand for $30 \mathrm{~min}$ at room temperature. The extinction of samples and the standards was read against the reagent blank at $662 \mathrm{~nm}$ on a UV-visible spectrophotometer. Net $\mathrm{N}$ mineralization for each treatment was quantified by subtracting extractable mineral $\mathrm{N}$ contents of the un- amended control soil from extractable mineral $\mathrm{N}$ contents found in each treatment ${ }^{56}$.

Available phosphorus in soil extracts was determined photometrically at $882 \mathrm{~nm}$ as a blue phosphate molybdic acid complex ${ }^{57}$. Briefly, $5 \mathrm{~g}$ of moist soil samples were extracted with $100 \mathrm{ml}$ of $0.5 \mathrm{M}$ sodium bicarbonate solution after shaking end-over-end for $30 \mathrm{~min}$. A $5 \mathrm{ml}$ of filtrate was pipetted into a beaker followed by adjustment of its $\mathrm{pH}$ at 5 with sulfuric acid and making up the volume to $20 \mathrm{ml}$. Sixteen $\mathrm{ml}$ of $0.001 \mathrm{M}$ ammonium heptamolybdate working solution were added to the mix followed by the addition of $2 \mathrm{ml}$ ascorbic acid. All the samples, controls and calibration standards were prepared in the similar way. After $15 \mathrm{~min}$, color complex of the solutions were measured at $882 \mathrm{~nm}$ on a UV-Visible spectrophotometer.

Cultivable heterotrophic bacteria were determined using the pour plate $\operatorname{method}^{27}$.. One $\mathrm{g}$ of fresh soil was suspended in $99 \mathrm{ml}$ buffered peptone water in $250 \mathrm{ml}$ a conical flask. After shaking flasks on an orbital shaker at $140 \mathrm{rpm}$ for $30 \mathrm{~min}$, serial dilutions were prepared and poured on nutrient agar. These inoculated plates were inoculated at $28^{\circ} \mathrm{C}$ for 3 days. After incubation, the colony forming units ( $\mathrm{cfu} \mathrm{ml}^{-1}$ ) were estimated by colony counter. 
Statistical analysis. Multiple factor analysis of variance (ANOVA) was used to assess the effect of $\mathrm{nZnO}$, $\mathrm{BC}$ and their interaction (i.e. $\mathrm{nZnO} \times \mathrm{BC}$ ) on soil $\mathrm{pH}$, microbial biomass $\mathrm{C}$, dissolved organic $\mathrm{C}$, metabolic quotient, ammonium, nitrate, mineral nitrogen, available phosphorus and bacterial colony forming units. In order to determine the treatment effects on carbon mineralization (rate \& cumulative), multiple factor ANOVA with $\mathrm{nZnO}, \mathrm{BC}$, time since incubation and their interaction as main factors was used. For both sets of ANOVAs used in the study, Post-hoc HSD test was used to distinguish the significantly different means at $95 \%$ confidence interval. All the statistical tests were performed using the STATGRAPHICS Centurion XVI software.

Received: 6 August 2020; Accepted: 7 April 2021

Published online: 19 April 2021

\section{References}

1. Klaine, S. J. et al. Nanomaterials in the environment: Behaviour, fate, bioavailability, and effects. Environ. Toxicol. Chem. 27, 1825-1851 (2008).

2. Seleiman, M. F. et al. Nano-fertilization as an emerging fertilization technique: why can modern agriculture benefit from its use?. Plants 10, 2 (2021).

3. Gruère, G., Narrod, C. \& Abbott, L. Agricultural, food, and water nanotechnologies for the poor (DC Int. Food Policy Res. Inst, 2011).

4. Dror, I., Yaron, B. \& Berkowitz, B. Abiotic soil changes induced by engineered nanomaterials: a critical review. J. Contam. Hydrol. 181, 3-16 (2015).

5. Kah, M., Beulke, S., Tiede, K. \& Hofmann, T. Nanopesticides: state of knowledge, environmental fate, and exposure modeling. Crit. Rev. Environ. Sci. Technol. (2013).

6. Zabrieski, Z. et al. Pesticidal activity of metal oxide nanoparticles on plant pathogenic isolates of Pythium. Ecotoxicology $\mathbf{2 4}$, 1305-1314 (2015).

7. $\mathrm{Hu}$, C. W. et al. Toxicological effects of TiO2and $\mathrm{ZnO}$ nanoparticles in soil on earthworm Eisenia fetida. Soil Biol. Biochem. 42, 586-591 (2010).

8. Parada, J. et al. The nanotechnology among US: are metal and metal oxides nanoparticles a nano or mega risk for soil microbial communities?. Crit. Rev. Biotechnol. 39, 157-172 (2019).

9. Seleiman, M. F. et al. Effects of $\mathrm{ZnO}$ nanoparticles and biochar of rice straw and cow manure on characteristics of contaminated soil and sunflower productivity, oil quality, and heavy metals uptake. Agronomy 10, 1-21 (2020).

10. Hermes, P.-H., Fabián, F.-L., Esperanza, H.-L., Jorge, M.-V. \& David, Á. -S. J. Effect of engineered nanoparticles on soil biota: do they improve the soil quality and crop production or jeopardize them?. L. Degrad. Dev. 50, 776-780 (2020).

11. Rashid, M. I. et al. Zinc oxide nanoparticles affect carbon and nitrogen mineralization of Phoenix dactylifera leaf litter in a sandy soil. J. Hazard. Mater. https://doi.org/10.1016/j.jhazmat.2016.10.063 (2016).

12. Shahzad, T. et al. Contribution of exudates, arbuscular mycorrhizal fungi and litter depositions to the rhizosphere priming effect induced by grassland species. Soil Biol. Biochem. 80, 146-155 (2015).

13. Dumont, E., Johnson, A. C., Keller, V. D. J. \& Williams, R. J. Nano silver and nano zinc-oxide in surface waters-exposure estimation for Europe at high spatial and temporal resolution. Environ. Pollut. 196, 341-349 (2015).

14. Prasanna, S. R. V. S., Balaji, K., Pandey, S. \& Rana, S. Chapter 4 - Metal Oxide Based Nanomaterials and Their Polymer Nanocomposites. in (ed. Karak, N. B. T.-N. and P. N.) 123-144 (Elsevier, 2019). https://doi.org/https://doi.org/10.1016/B978-0-12-814615-6. 00004-7

15. Dinesh, R., Anandaraj, M., Srinivasan, V. \& Hamza, S. Engineered nanoparticles in the soil and their potential implications to microbial activity. Geoderma 173-174, 19-27 (2012).

16. Jeffery, S., Verheijen, F. G. A., van der Velde, M. \& Bastos, A. C. A quantitative review of the effects of biochar application to soils on crop productivity using meta-analysis. Agric. Ecosyst. Environ. 144, 175-187 (2011).

17. Riaz, M. et al. Corncob-derived biochar decelerates mineralization of native and added organic matter (AOM) in organic matter depleted alkaline soil. Geoderma 294, 19-28 (2017).

18. Seleiman, M. F. et al. Integrative effects of rice-straw biochar and silicon on oil and seed quality, yield and physiological traits of Helianthus annuus L. grown under water deficit stress. Agronomy 9, 637 (2019).

19. O'Connor, D. et al. Biochar application for the remediation of heavy metal polluted land: a review of in situ field trials. Sci. Total Environ. 619-620, 815-826 (2018).

20. Zhang, X. et al. Using biochar for remediation of soils contaminated with heavy metals and organic pollutants. Environ. Sci. Pollut. Res. 20, 8472-8483 (2013).

21. Gonçalves, S. P. C., Strauss, M. \& Martinez, D. S. T. The positive fate of biochar addition to soil in the degradation of PHBV-silver nanoparticle composites. Environ. Sci. Technol. 52, 13845-13853 (2018).

22. Taş, A. C., Majewski, P. J. \& Aldinger, F. Synthesis of gallium oxide hydroxide crystals in aqueous solutions with or without urea and their calcination behavior. J. Am. Ceram. Soc. 85, 1421-1429 (2002).

23. Huang, J. et al. Biosynthesis of silver and gold nanoparticles by novel sundried Cinnamomum camphora leaf. Nanotechnology 18 , 105104 (2007).

24. Nagarajan, S. \& Kuppusamy, K. A. Extracellular synthesis of zinc oxide nanoparticle using seaweeds of gulf of Mannar, India. J. Nanobiotechnol. 11, 1-11 (2013).

25. Siddique, K. et al. Comparative efficacy of biogenic zinc oxide nanoparticles synthesized by Pseudochrobactrum sp. C5 and chemically synthesized zinc oxide nanoparticles for catalytic degradation of dyes and wastewater treatment. Environ. Sci. Pollut. Res. https://doi.org/10.1007/s11356-021-12575-9 (2021).

26. Ge, Y., Schimel, J. P. \& Holden, P. A. Evidence for negative effects of $\mathrm{TiO}_{2}$ and $\mathrm{ZnO}$ nanoparticles on soil bacterial communities evidence for negative effects of $\mathrm{TiO}_{2}$ and $\mathrm{ZnO}$ nanoparticles on soil bacterial communities. Environ. Sci. Technol. 45, 1659-1664. https://doi.org/10.1021/es103040t (2011).

27. Rashid, M. I. et al. Toxicity of iron oxide nanoparticles to grass litter decomposition in a sandy soil. Sci. Rep. 7, 41965 (2017).

28. Jośko, I., Oleszczuk, P. \& Futa, B. The effect of inorganic nanoparticles $(\mathrm{ZnO}, \mathrm{Cr} 2 \mathrm{O} 3, \mathrm{CuO}$ and $\mathrm{Ni}$ ) and their bulk counterparts on enzyme activities in different soils. Geoderma 232-234, 528-537 (2014).

29. Asadishad, B. et al. Amendment of agricultural soil with metal nanoparticles: effects on soil enzyme activity and microbial community composition. Environ. Sci. Technol. 52, 1908-1918 (2018).

30. Jośko, I. et al. Long-term effect of $\mathrm{ZnO}$ and $\mathrm{CuO}$ nanoparticles on soil microbial community in different types of soil. Geoderma 352, 204-212 (2019).

31. Khan, M. \& Scullion, J. Effects of metal ( $\mathrm{Cd}, \mathrm{Cu}, \mathrm{Ni}, \mathrm{Pb}$ or $\mathrm{Zn})$ enrichment of sewage-sludge on soil micro-organisms and their activities. Appl. Soil Ecol. 20, 145-155 (2002). 
32. Biederman, L. A. \& Harpole, W. S. Biochar and its effects on plant productivity and nutrient cycling: a meta-analysis. GCB Bioenergy 5, 202-214 (2013).

33. Dempster, D. N., Gleeson, D. B., Solaiman, Z. M., Jones, D. L. \& Murphy, D. V. Decreased soil microbial biomass and nitrogen mineralisation with Eucalyptus biochar addition to a coarse textured soil. Plant Soil 354, 311-324 (2012).

34. Yin, Y., He, X., Gao, R., Ma, H. \& Yang, Y. Effects of rice straw and its biochar addition on soil labile carbon and soil organic carbon. J. Integr. Agric. 13, 491-498 (2014).

35. García-gómez, C. et al. Soil pH effects on the toxicity of zinc oxide nanoparticles to soil microbial community. Environ. Sci. Pollut. Res. 25, 28140 (2018).

36. Sri Sindhura, K., Prasad, T. N. V. K. V., Panner Selvam, P. \& Hussain, O. M. Synthesis, characterization and evaluation of effect of phytogenic zinc nanoparticles on soil exo-enzymes. Appl. Nanosci. 4, 819-827 (2014).

37. Bardgett, R. D. \& Saggar, S. Effects of heavy metal contamination on the short-term decomposition of labelled [14C]glucose in a pasture soil. Soil Biol. Biochem. 26, 727-733 (1994).

38. Dornbush, M. E. Grasses, litter, and their interaction affect microbial biomass and soil enzyme activity. Soil Biol. Biochem. 39, 2241-2249 (2007).

39. Jiang, X., Haddix, M. L. \& Cotrufo, M. F. Interactions between biochar and soil organic carbon decomposition: effects of nitrogen and low molecular weight carbon compound addition. Soil Biol. Biochem. 100, 92-101 (2016).

40. McDonald, G. K. et al. A survey of total and dissolved organic carbon in alkaline soils of southern Australia. Soil Res. 55, 617-629 (2017).

41. El-Naggar, A. H. et al. Carbon mineralization and nutrient availability in calcareous sandy soils amended with woody waste biochar. Chemosphere 138, 67-73 (2015).

42. Zhu, D. et al. Synthesis and characterization of magnesium oxide nanoparticle-containing biochar composites for efficient phosphorus removal from aqueous solution. Chemosphere 247, 125848 (2020).

43. Bruinink, A., Wang, J. \& Wick, P. Effect of particle agglomeration in nanotoxicology. Arch. Toxicol. 89, 659-675 (2015).

44. Zare, Y., Rhee, K. Y. \& Hui, D. Influences of nanoparticles aggregation/agglomeration on the interfacial/interphase and tensile properties of nanocomposites. Compos. Part B Eng. 122, 41-46 (2017).

45. Shahzad, T. et al. Root penetration in deep soil layers stimulates mineralization of millennia-old organic carbon. Soil Biol. Biochem. 124, 150-160 (2018).

46. Waalewijn-Kool, P. L., Diez Ortiz, M. \& van Gestel, C. A. M. Effect of different spiking procedures on the distribution and toxicity of ZnO nanoparticles in soil. Ecotoxicology 21, 1797-1804 (2012).

47. Rehman, K. et al. Effect of Reactive Black 5 azo dye on soil processes related to $C$ and N cycling. PeerJ 2018, (2018).

48. Zibilske, L. M. Carbon mineralization. in Methods of Soil Analysis Part 2, Microbiological and Biochemical Properties (eds. Weaver, R. W. et al.) 835-864 (SSSA, 1994).

49. Vance, E. D., Brookes, P. C. \& Jenkinson, D. S. An extraction method for measuring soil microbial biomass C. Soil Biol. Biochem. 19, 703-707 (1987).

50. Jackson, M. L. Soil chemical analysis, constable and Co. Ltd. London 497, (1962).

51. Walkley, A. \& Black, I. A. An examination of the Degtjareff method for determining soil organic matter, and a proposed modification of the chromic acid titration method. Soil Sci. 37, 29-38 (1934).

52. Joergensen, R. G. The fumigation-extraction method to estimate soil microbial biomass: Calibration of the kEC value. Soil Biol. Biochem. 28, 25-31 (1996).

53. Jones, D. L. \& Willett, V. B. Experimental evaluation of methods to quantify dissolved organic nitrogen (DON) and dissolved organic carbon (DOC) in soil. Soil Biol. Biochem. 38, 991-999 (2006).

54. Cataldo, D. A., Maroon, M., Schrader, L. E. \& Youngs, V. L. Rapid colorimetric determination of nitrate in plant tissue by nitration of salicylic acid. Commun. Soil Sci. Plant Anal. 6, 71-80 (1975).

55. Keeney, D. R. \& Nelson, D. W. Nitrogen - Inorganic forms. in Methods of Soil Analysis, Part 2 (eds. Page, A. L. \& Miller, R. H.) 643-698 (American Society of Agronomy, 1982).

56. Sierra, J. Temperature and soil moisture dependence of $\mathrm{N}$ mineralization in intact soil cores. Soil Biol. Biochem. 29, 1557-1563 (1997).

57. Olsen, S. R., Sommers, L. E. \& Page, A. L. Methods of soil analysis. Part 2, 403-430 (1982)

\section{Acknowledgements}

This work was funded by Government College University, Faisalabad, and The ILSI Research Foundation (BRPGP010-13).

\section{Author contributions}

S, T.S. and S.H. conceived the experiment, S, A.M., F.M. and M.I. conducted and helped in analyses, M.S., M.I., M.A.A. and T.S. interpreted the data, S and T.S. wrote the first draft and all the authors contributed to improve the final draft.

\section{Competing interests}

The authors declare no competing interests.

\section{Additional information}

Supplementary Information The online version contains supplementary material available at https://doi.org/ 10.1038/s41598-021-88016-x.

Correspondence and requests for materials should be addressed to T.S.

Reprints and permissions information is available at www.nature.com/reprints.

Publisher's note Springer Nature remains neutral with regard to jurisdictional claims in published maps and institutional affiliations. 
(c) (i) Open Access This article is licensed under a Creative Commons Attribution 4.0 International cc) License, which permits use, sharing, adaptation, distribution and reproduction in any medium or format, as long as you give appropriate credit to the original author(s) and the source, provide a link to the Creative Commons licence, and indicate if changes were made. The images or other third party material in this article are included in the article's Creative Commons licence, unless indicated otherwise in a credit line to the material. If material is not included in the article's Creative Commons licence and your intended use is not permitted by statutory regulation or exceeds the permitted use, you will need to obtain permission directly from the copyright holder. To view a copy of this licence, visit http://creativecommons.org/licenses/by/4.0/.

(C) The Author(s) 2021 